\title{
Developing Function Models of Back-to-Back PWM Converters for Simplified Simulation
}

\author{
Tan Luong Van* and Dong-Choon Lee ${ }^{\dagger}$ \\ $\dagger^{*}$ Dept. of Electrical Engineering, Yeungnam University, Gyeongsan, Korea
}

\begin{abstract}
In this paper, a function model of back-to-back PWM converters, based on the switching function, is developed for simplified simulation of power electronic application systems. For the function model, the PWM power switches are represented by dependent power sources. By using the proposed function model, the computer memory and the run time required for the simulation of power circuits can be significantly reduced. It is shown that the simulation results generated from the function models are almost the same as the ones obtained by using the switching power device model.
\end{abstract}

Key Words: Back-to-back PWM converters, Function model, Switching function

\section{INTRODUCTION}

Power converter circuits can be analyzed and designed effectively thanks to the support of powerful simulation programs such as Pspice, Matlab, and PSCAD. With Pspice, power converter circuits can be schematically described by utilizing actual power switching device models and passive components. Also, Pspice is suitable for designing and studying the switching losses of circuits such as power system configurations, snubber circuits and so on. Nevertheless, these models are expressed as nonlinear controlled-sources that result in long execution times, large amounts of generated data, and potential convergence problems [1]-[3].

In the case of Matlab, power converter circuits can be described by state equations. Based on these equations, the modeling of circuits can be easily performed with the support of the functional blocks in Matlab simulink. However, utilizing the state equations according to the circuit configuration is a time-consuming task. Besides that, if there are any minor changes in the circuit configuration, a new circuit should be derived due to the changes in the state equations [4].

Recently, the PSCAD simulation tool has become widely used in the different fields of power systems. The models of actual electronic power devices can be utilized to express the circuits. Also, the system circuits can be designed by using the basic functional blocks which are available in the PSCAD library or built from the state equations. However, these models have the limitation of a lengthy simulation time. Therefore, a simplified function model of power converter circuits, which is not based on actual semiconductor device models, is desirable. The switching function concept and function models have been

\footnotetext{
Manuscript received May 9, 2010; revised Sep. 7, 2010

$\dagger$ Corresponding Author: dclee@yu.ac.kr

Tel: +82-53-810-2582, Fax: +82-53-810-4767, Yeungnam University

* Dept. of Electrical Eng., Yeungnam University, Korea
}

used for understanding and optimizing the performance of power converters.

In this paper, functional models for back-to-back PWM converters are developed, based on the switching function theory. These developed models have the following advantages:

1) Simplified function models of back-to-back PWM converters can be obtained for simulation work.

2) The convergence issue can be removed and the execution time for simulations is greatly reduced.

3) The resultant transfer equations and the dependent power sources are combined to represent function models of the actual semiconductor devices.

4) They can be easily applied to other power conversion circuits such as PWM multi-level converters.

Simulations in the two cases of an actual switching device model and a function model are performed and the validity of the proposed model is shown.

\section{SWITChING PRINCIPLE OF BACK-TO-BACK PWM CONVERTERS}

\section{A. Two-level converters}

A power circuit of three-phase voltage-source back-toback PWM converters including twelve power semiconductor switches is shown in Fig. 1, where the two converters are linked through a DC capacitor. As can be seen in Fig. 1, the $\mathrm{AC} / \mathrm{DC}$ converter has three input voltages $\left(v_{a}(t), v_{b}(t), v_{c}(t)\right)$ and produces an output voltage $\left(V_{d c}\right)$, which is the input voltage of the inverter, whereas the three phase voltages $\left(v_{a}^{\prime}(t), v_{b}^{\prime}(t), v_{c}^{\prime}(t)\right)$ designate the output terminal of the inverter.

1) AC/DC Converter Side: As shown in the left-hand part of Fig. 1, the circuit of an AC/DC converter can be represented as a simplified equivalent circuit with a switch (single-pole 


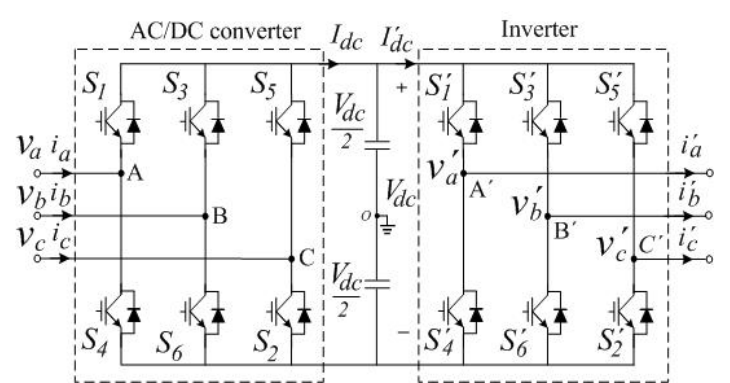

Fig. 1. Circuit configuration of two-level back-to-back PWM converters.

TABLE I

SWitching States OF TWO-LEVEl ThreE-PHASE CONVERTERS

\begin{tabular}{|c|c|c|c|c|c|c|}
\hline \multicolumn{6}{|c|}{ Switching states } & \multirow{2}{*}{$\begin{array}{c}\text { Input voltage } \\
\left(v_{a b}\right)\end{array}$} \\
\hline$S_{1}$ & $S_{2}$ & $S_{3}$ & $S_{4}$ & $S_{5}$ & $S_{6}$ & \\
\hline 1 & 0 & 0 & 0 & 0 & 1 & $+V_{d c} / 2$ \\
\hline 1 & 1 & 0 & 0 & 0 & 0 & $+V_{d c} / 2$ \\
\hline 0 & 1 & 1 & 0 & 0 & 0 & 0 \\
\hline 0 & 0 & 1 & 1 & 0 & 0 & $-V_{d c} / 2$ \\
\hline 0 & 0 & 0 & 1 & 1 & 0 & $-V_{d c} / 2$ \\
\hline 0 & 0 & 0 & 0 & 1 & 1 & 0 \\
\hline
\end{tabular}

double-throw) in each leg as shown in Fig. 2 [5], [6]. The switching states of the switches and the input voltage for threephase converters are listed in Table I.

For the SPWM technique in Fig. 3(a), a triangular carrier waveform $\left(v_{t r i}\right)$ is compared with the reference sinusoidal waveform $\left(v_{m o d}\right)$ at the fundamental frequency of the output voltage. Then, the switching pulses $\left(S_{1}, S_{4}\right)$ for phase A are determined as shown in Fig. 3(b) and (c). With these modulated waveforms, the two-level switching functions $\left(S_{a}(t), S_{b}(t), S_{c}(t)\right)$ for each leg of the AC/DC converter shown in Fig. 3(d) can be expressed as [4].

$$
\begin{aligned}
& S_{a}(t)=\frac{1}{2}\left(S_{1}-S_{4}\right) \\
& S_{b}(t)=\frac{1}{2}\left(S_{3}-S_{6}\right) \\
& S_{c}(t)=\frac{1}{2}\left(S_{5}-S_{2}\right) .
\end{aligned}
$$

2) Inverter Side: Considering the circuit of an inverter as shown in the right-hand part of Fig. 1, an equivalent circuit with a switch in each leg can be simplified as in Fig. 4 [5], [6]. The switching states of the switches and the output voltages for the inverter are similar to those of an AC/DC converter. Thus, the two-level switching functions $\left(S_{a}^{\prime}(t), S_{b}^{\prime}(t), S_{c}^{\prime}(t)\right)$ for the legs of the converters expressing the states of the twolevel PWM converters can be represented as:

$$
S_{x}=\left\{\begin{array}{l}
1, \text { upper switch ON } \\
0, \text { lower switch ON }
\end{array}\right.
$$

where the subscript $x$ represents the phases a, b, c for the three legs.

3) Two-level Back-to-Back PWM Converters : An equivalent circuit of two-level back-to-back PWM converters is shown in Fig. 5. With this circuit, each of the converters utilizes only six switches instead of twelve as in the model of the actual power electronic devices.

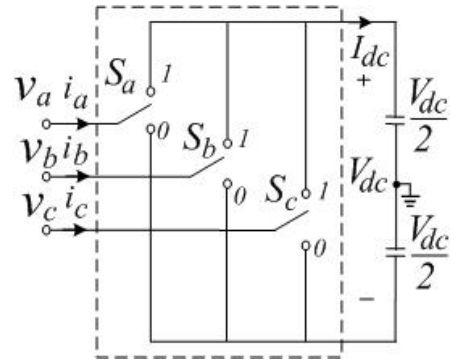

Fig. 2. Equivalent circuit of two-level AC/DC PWM converter.
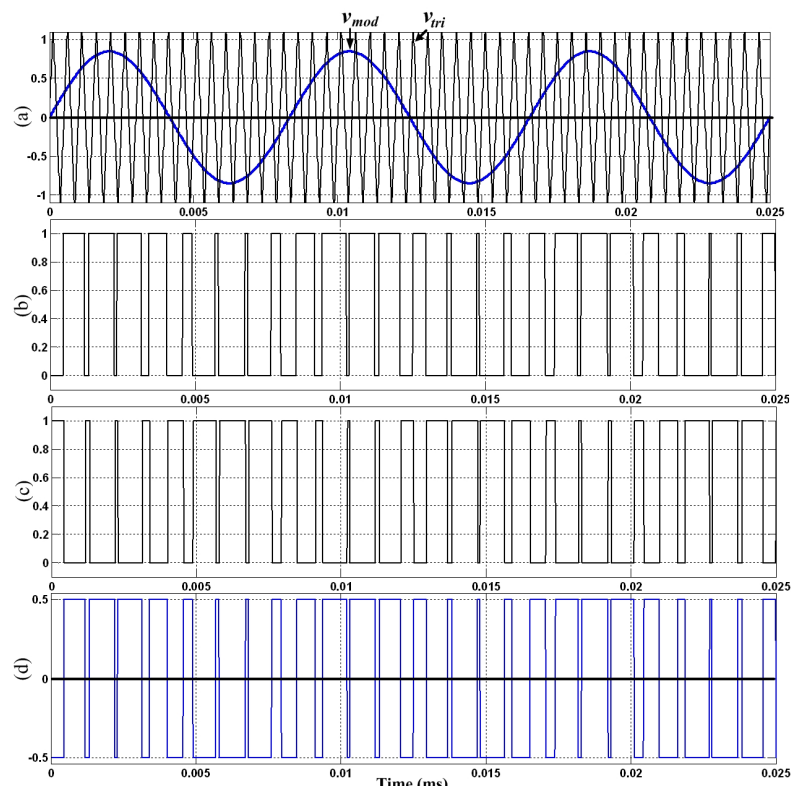

Fig. 3. SPWM and switching pulses for leg of phase A.

(a) Carrier $\left(v_{t r i}\right)$ and control $\left(v_{\text {mod }}\right)$ signals.

(b) Switching pulse $\left(S_{1}\right)$.

(c) Switching pulse $\left(S_{4}\right)$.

(d) Switching function $\left(S_{a}\right)$.

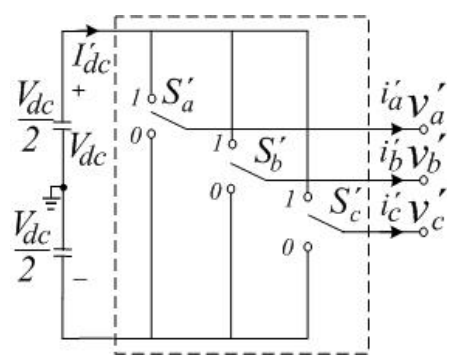

Fig. 4. Equivalent circuit of two-level inverter.

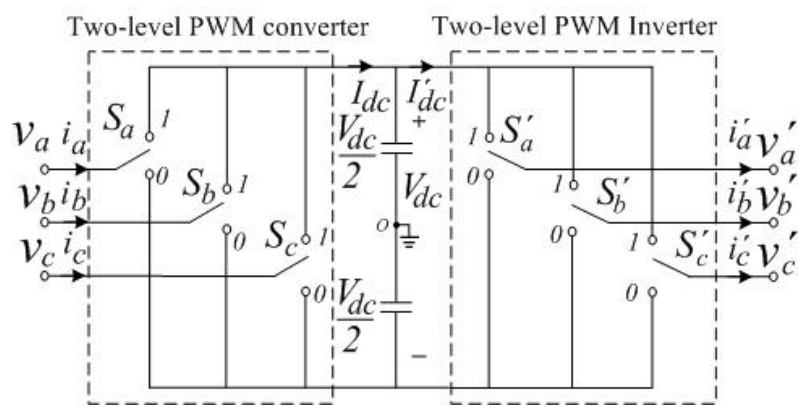

Fig. 5. Equivalent circuit of two-level back-to-back PWM converters. 


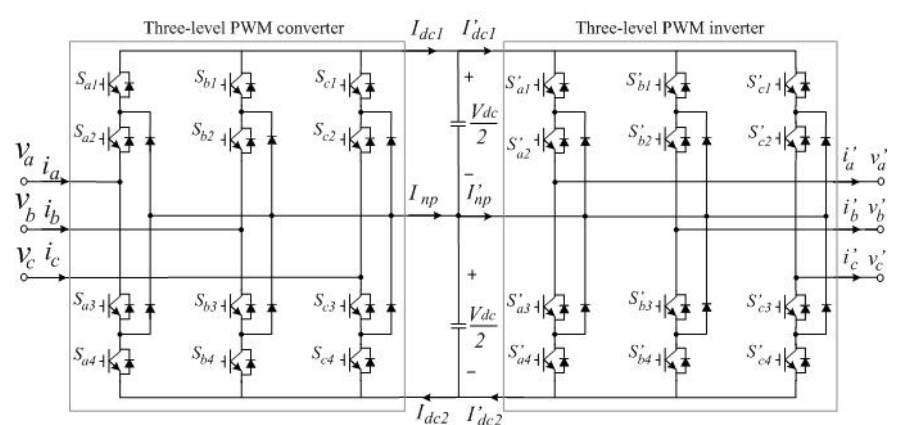

Fig. 6. Circuit configuration of three-level back-to-back PWM converters.

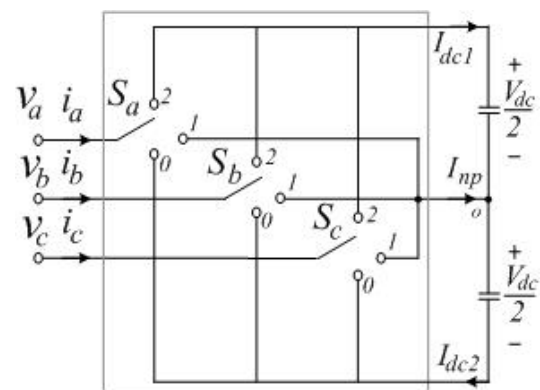

Fig. 7. Equivalent circuit of three-level AC/DC PWM converters.

\section{B. Three-level converters}

The circuit configuration of three-level back-to-back PWM converters consists of two neutral-point clamped converters, linked through DC capacitors, which is shown in Fig. 6. Each converter uses twelve switches and six additional diodes.

1) AC/DC Converter Side: The circuit of an AC/DC neutral-point clamped converter, shown in left-hand part of Fig. 6, is simplified with an equivalent circuit with a switch in each leg as shown in Fig. 7 [5], [6].

The switching states for the four switches of each phase and the input phase voltages for the AC/DC converters are described in Table II.

To generate the switching pulses for the converters, two carrier waveforms $\left(v_{t r i 1}, v_{t r i 2}\right)$ are simultaneously compared with a sinusoidal waveform $\left(v_{\text {mod }}\right)$ at the fundamental frequency as shown in Fig. 8 (a). In the case of phase A, for instances, the switching pulses $\left(S_{a 1}, S_{a 2}, S_{a 3}, S_{a 4}\right)$ are illustrated in Fig. 8 (b), (c), (d) and (e) [5]. From these switching pulses, the three-level switching function $\left(S_{a}\right)$ for a leg of phase $\mathrm{A}$ is determined as in Fig. 8(f), where the switching states ' 1 ' and ' 0 ' represent that the switch is in the 'on' and the 'off' condition, respectively. Also, the neutral-point voltage is controlled to avoid deviations between the upper voltage and the lower voltage due to inconsistencies in the switching device characteristics [7].

2) Inverter Side: As shown in Fig. 9, a simplified equivalent circuit with a switch in each leg can be replaced by a circuit as in the right-hand part of Fig. 6 [5], [6].

TABLE II

SWitching States of Three-LEVEL THREe-PHASE CONVERTERS

\begin{tabular}{|c|c|c|c|c|c|}
\hline$S_{a 1}$ & $S_{a 2}$ & $S_{a 3}$ & $S_{a 4}$ & $\begin{array}{c}\text { Switching } \\
\text { states }\left(S_{a}\right)\end{array}$ & $\begin{array}{c}\text { Phase voltage } \\
\left(v_{a o}\right)\end{array}$ \\
\hline 1 & 1 & 0 & 0 & + & $+V_{d c} / 2$ \\
\hline 0 & 1 & 1 & 0 & 0 & 0 \\
\hline 0 & 0 & 1 & 1 & - & $-V_{d c} / 2$ \\
\hline
\end{tabular}

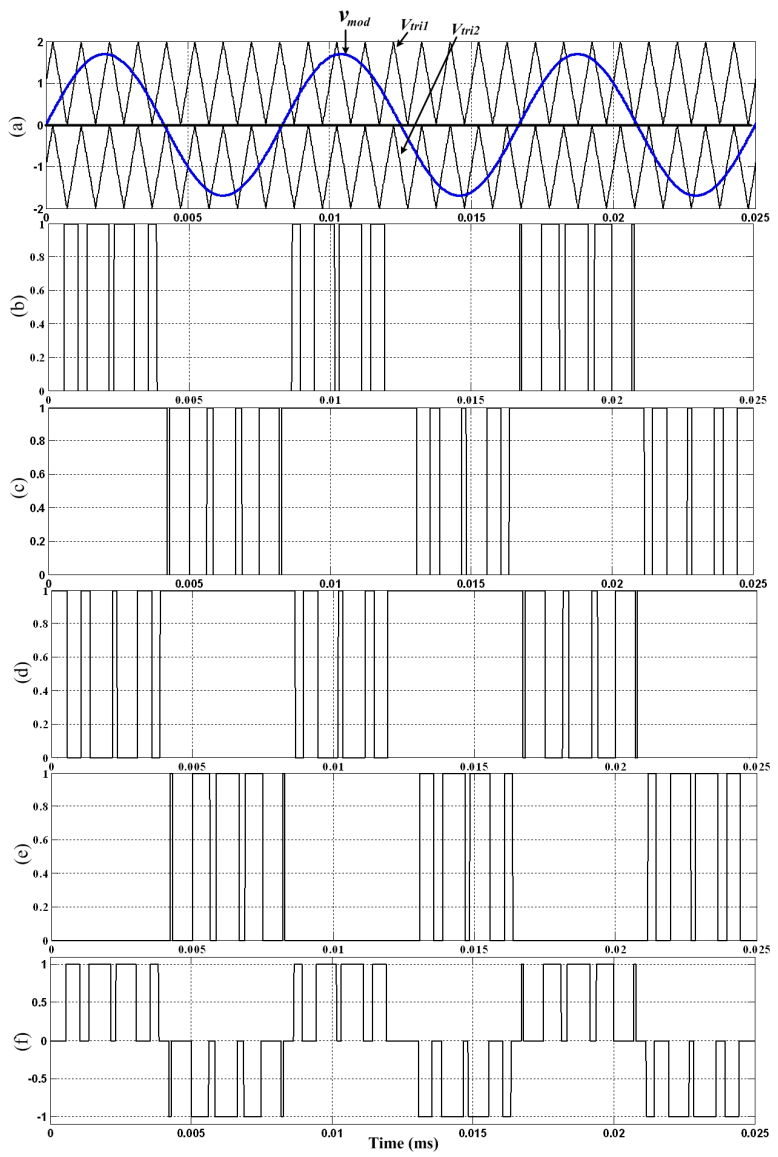

Fig. 8. SPWM and switching pulses for three-level converters.

(a) Carrier $\left(v_{\text {tri } 1}, v_{\text {tri2 }}\right)$ and control $\left(v_{\text {mod }}\right)$ signals.

(b) Switching pulse $\left(S_{a 1}\right)$.

(c) Switching pulse $\left(S_{a 2}\right)$.

(d) Switching pulse $\left(S_{a 3}\right)$.

(e) Switching pulse $\left(S_{a 4}\right)$.

(f) Three-level switching function $\left(S_{a}\right)$.

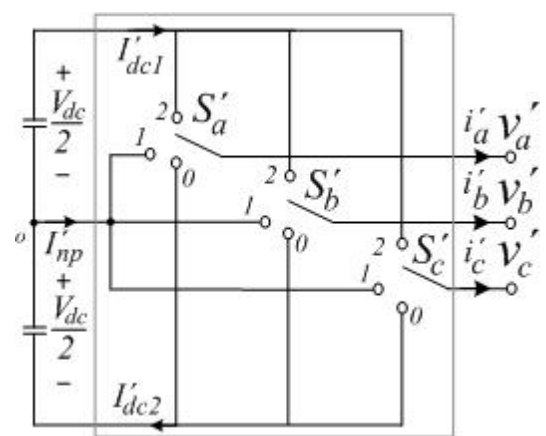

Fig. 9. Equivalent circuit of three-level inverter.

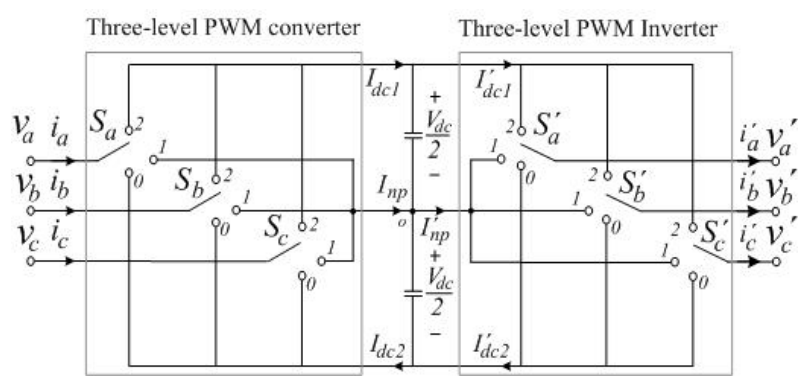

Fig. 10. Simplified equivalent circuit of three-level back-to-back PWM converters. 


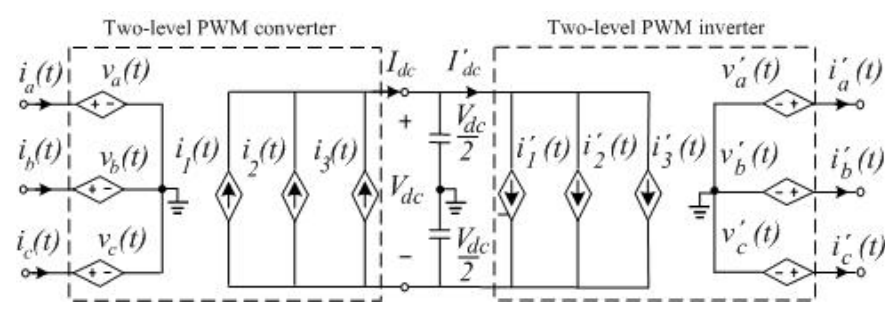

Fig. 11. Overall functional model of two-level back-to-back PWM converters.

The three-level switching functions $\left(S_{a}^{\prime}(t), S_{b}^{\prime}(t), S_{c}^{\prime}(t)\right)$ for the legs of an inverter are similar to those of an AC/DC converter. Thus, the switching functions for three-level PWM converters can be generally expressed as [7]-[10].

$$
S_{x}=\left\{\begin{array}{cc}
1, \text { upper switch } 2 \text { ON } & S_{x 1}, S_{x 2}: \text { ON } \\
0, \text { middle switch } 1 \text { ON } & S_{x 2}, S_{x 3}: \text { ON } \\
-1, \text { lower switch } 0 \text { ON } & S_{x 3}, S_{x 4}: \text { ON }
\end{array}\right.
$$

wherexrepresents phases $\mathrm{a}, \mathrm{b}, \mathrm{c}$ for the three legs.

3) Three-level Back-to-Back PWM Converters: An equivalent circuit composed of one switch in each leg of three-level back-to-back PWM converters is drawn in Fig. 10 [6].

\section{MOdELING OF TWO-LEVEL BACK-TO-BACK PWM CONVERTERS}

\section{A. Converter Model}

The input voltages $\left(v_{a}(t), v_{b}(t), v_{c}(t)\right)$ are made up by reflecting the output voltage $\left(V_{d c}\right)$ to the input terminal, and the output current $\left(I_{d c}\right)$ is composed by reflecting the input currents $\left(i_{a}(t), i_{b}(t), i_{c}(t)\right)$ to the output terminal. This is accomplished using switching functions. These reflecting procedures can be formulated as followings:

Input voltage $\left(v_{a}(t), v_{b}(t), v_{c}(t)\right)$ :

$$
\begin{aligned}
& v_{a}(t)=S_{a}(t) \cdot V_{d c} \\
& v_{b}(t)=S_{b}(t) \cdot V_{d c} . \\
& v_{c}(t)=S_{c}(t) \cdot V_{d c}
\end{aligned}
$$

Output current $\left(I_{d c}\right)$ :

$$
\begin{aligned}
I_{d c} & =i_{1}(t)+i_{2}(t)+i_{3}(t) \\
& =S_{a}(t) \cdot i_{a}(t)+S_{b}(t) \cdot i_{b}(t)+S_{c}(t) \cdot i_{c}(t),
\end{aligned}
$$

where $S_{a}(t), S_{b}(t)$, and $S_{c}(t)$ are switching functions for each leg of a two-level AC/DC converter. The function model for an AC/DC converter is shown in the left-hand part of Fig. 11.

\section{B. Inverter Model}

For the inverter model, the inputs and outputs are swapped with those of the AC/DC converters. Hence:

Input current $\left(I_{d c}^{\prime}\right)$ :

$$
\begin{aligned}
I_{d c}^{\prime} & =i_{1}^{\prime}(t)+i_{2}^{\prime}(t)+i_{3}^{\prime}(t) \\
& =S_{a}^{\prime}(t) \cdot i_{a}^{\prime}(t)+S_{b}^{\prime}(t) \cdot i_{b}^{\prime}(t)+S_{c}^{\prime}(t) \cdot i_{c}^{\prime}(t) .
\end{aligned}
$$

Output voltage $\left(v_{a}^{\prime}(t), v_{b}^{\prime}(t), v_{c}^{\prime}(t)\right)$ :

$$
\begin{aligned}
& v_{a}^{\prime}(t)=S_{a}^{\prime}(t) \cdot V_{d c} \\
& v_{b}^{\prime}(t)=S_{b}^{\prime}(t) \cdot V_{d c} \\
& v_{c}^{\prime}(t)=S_{c}^{\prime}(t) \cdot V_{d c},
\end{aligned}
$$

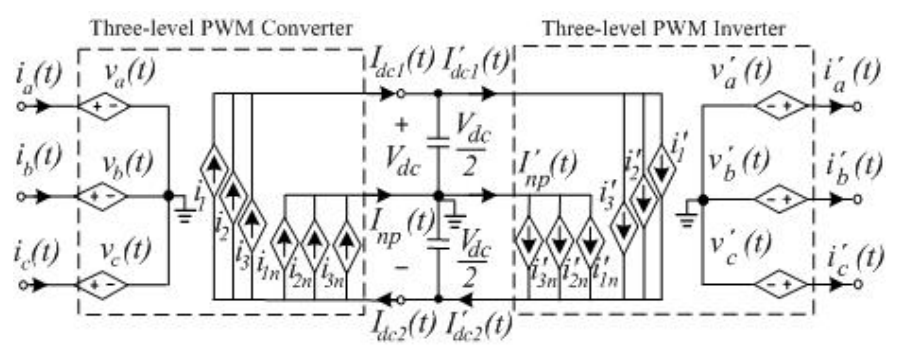

Fig. 12. Overall functional model of three-level back-to-back PWM converters.

where $S_{a}^{\prime}(t), S_{b}^{\prime}(t)$, and $S_{c}^{\prime}(t)$ are switching functions for each leg of the two-level inverters. The equivalent circuit using a function model of a two-level PWM inverter is shown in the right-hand part of Fig. 11.

\section{Modeling OF THEe-LEVEl BACK-TO-BACK PWM CONVERTERS}

\section{A. Converter Model}

The procedures reflecting the relations between the output voltage $\left(V_{d c}\right)$ and the input terminals $\left(v_{a}(t), v_{b}(t), v_{c}(t)\right)$, as well as the input currents $\left(i_{a}(t), i_{b}(t), i_{c}(t)\right)$ and the output terminal $\left(I_{d c}\right)$ by using switching functions can be expressed as follows:

Input voltage $\left(v_{a}(t), v_{b}(t), v_{c}(t)\right)$ :

$$
\begin{aligned}
& v_{a}(t)=S_{a}(t) \cdot \frac{V_{d c}}{2} \\
& v_{b}(t)=S_{b}(t) \cdot \frac{V_{d c}}{2} \\
& v_{c}(t)=S_{c}(t) \cdot \frac{V_{d c}}{2} .
\end{aligned}
$$

Output current $\left(I_{d c 1}, I_{d c 2}, I_{n p}\right)$ :

$$
\begin{aligned}
I_{d c 1} & =i_{1}(t)+i_{2}(t)+i_{3}(t) \\
& =\operatorname{sign} 1\left(S_{a}(t)\right) \cdot i_{a}(t)+\operatorname{sign} 1\left(S_{b}(t)\right) \cdot i_{b}(t)+\operatorname{sign} 1\left(S_{c}(t)\right) \cdot i_{c}(t),
\end{aligned}
$$

$$
\begin{aligned}
I_{d c 2} & =\operatorname{sign} 2\left(S_{a}(t)\right) \cdot i_{a}(t)+\operatorname{sign} 2\left(S_{b}(t)\right) \cdot i_{b}(t)+\operatorname{sign} 2\left(S_{c}(t)\right) \cdot i_{c}(t), \\
I_{n p} & =i_{1 n}(t)+i_{2 n}(t)+i_{3 n}(t) \\
& =\operatorname{sign} 3\left(S_{a}(t)\right) \cdot i_{a}(t)+\operatorname{sign} 3\left(S_{b}(t)\right) \cdot i_{b}(t)+\operatorname{sign} 3\left(S_{c}(t)\right) \cdot i_{c}(t),
\end{aligned}
$$

where

$$
\begin{aligned}
& \operatorname{sign} 1(x)=\left\{\begin{array}{l}
1, x>0 \\
0, x \leq 0
\end{array}, \operatorname{sign} 2(x)=\left\{\begin{array}{l}
0, x \geq 0 \\
-1, x<0
\end{array},\right.\right. \\
& \operatorname{sign} 3(x)=\left\{\begin{array}{l}
1, x=0 \\
0, x \neq 0
\end{array}\right.
\end{aligned}
$$

The equivalent circuit for the function model of a three-level PWM AC/DC converter is shown in the left-hand part of Fig. 12. 


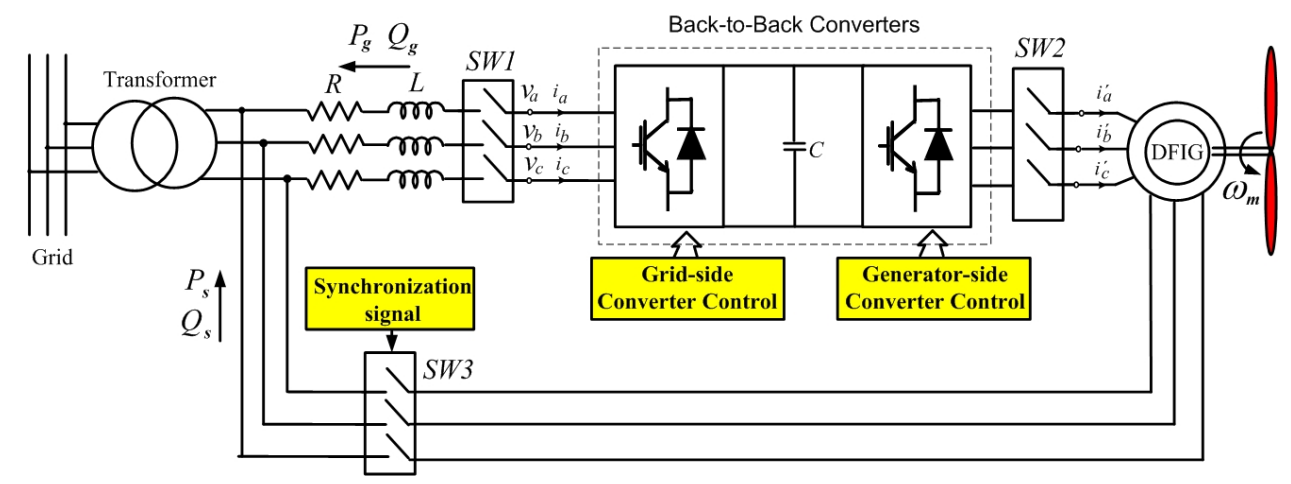

Fig. 13. DFIG wind power system using back-to-back PWM converters.

\section{B. Inverter Model}

For the inverter model, the inputs and the outputs are obtained by exchanging these two quantities in the AC/DC converter.

Input current $\left(I_{d c 1}^{\prime}, I_{d c 2}^{\prime}, I_{n p}^{\prime}\right)$ :

$$
\begin{aligned}
I_{d c 1}^{\prime} & =i_{1}^{\prime}(t)+i_{2}^{\prime}(t)+i_{3}^{\prime}(t) \\
& =\operatorname{sign} 1\left(S_{a}^{\prime}(t)\right) \cdot i_{a}^{\prime}(t)+\operatorname{sign} 1\left(S_{b}^{\prime}(t)\right) \cdot i_{b}^{\prime}(t)+\operatorname{sign} 1\left(S_{c}^{\prime}(t)\right) \cdot i_{c}^{\prime}(t
\end{aligned}
$$

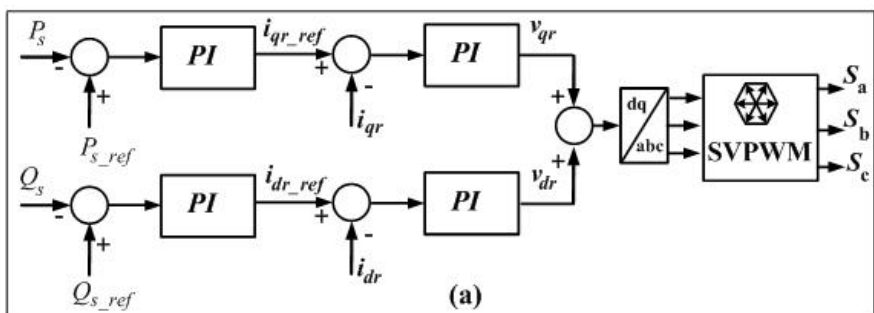

$$
I_{d c 2}^{\prime}=\operatorname{sign} 2\left(S_{a}^{\prime}(t)\right) \cdot i_{a}^{\prime}(t)+\operatorname{sign} 2\left(S_{b}^{\prime}(t)\right) \cdot i_{b}^{\prime}(t)
$$

$$
+\operatorname{sign} 2\left(S_{c}^{\prime}(t)\right) \cdot i_{c}^{\prime}(t)
$$

$I_{n p}^{\prime}=i_{1 n}^{\prime}(t)+i_{2 n}^{\prime}(t)+i_{3 n}^{\prime}(t)$

$$
=\operatorname{sign} 3\left(S_{a}^{\prime}(t)\right) \cdot i_{a}^{\prime}(t)+\operatorname{sign} 3\left(S_{b}^{\prime}(t)\right) \cdot i_{b}^{\prime}(t)+\operatorname{sign} 3\left(S_{c}^{\prime}(t)\right) \cdot i_{c}^{\prime}(t
$$

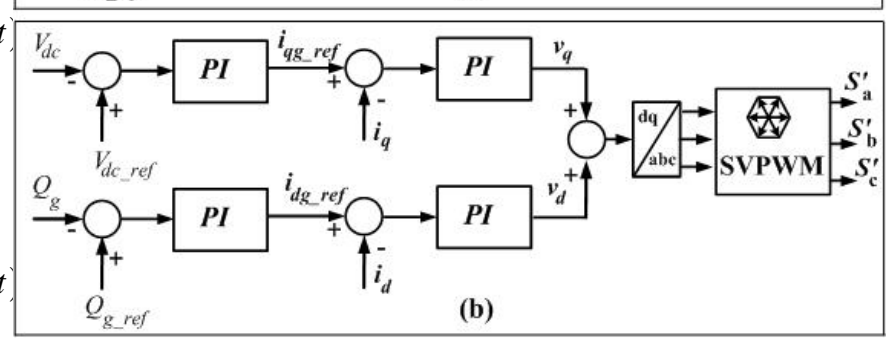

Output voltage $\left(v_{a}^{\prime}(t), v_{b}^{\prime}(t), v_{c}^{\prime}(t)\right)$ :

$$
\begin{aligned}
& v_{a}^{\prime}(t)=S_{a}^{\prime}(t) \cdot \frac{V_{d c}}{2} \\
& v_{b}^{\prime}(t)=S_{b}^{\prime}(t) \cdot \frac{V_{d c}}{2} \\
& v_{c}^{\prime}(t)=S_{c}^{\prime}(t) \cdot \frac{V_{d c}}{2} .
\end{aligned}
$$

where $S_{a}^{\prime}(t), S_{b}^{\prime}(t)$, and $S_{c}^{\prime}(t)$ are the switching functions for each leg of a three-level inverter. An equivalent circuit for the function model of a three-level PWM inverter is shown in the right-hand part of Fig. 12.

\section{Application ExAmple}

A doubly-fed induction generator (DFIG) is essentially a wound rotor induction generator with slip rings. The stator is connected directly to the grid, and the rotor is interfaced with the grid through partially rated back-to-back PWM converters, which only have to handle a fraction $(25 \%-30 \%)$ of the total DFIG power to achieve a full control of the generator. Either two-level or three-level back-to-back PWM converters of a DFIG wind turbine system are connected together through DC capacitors as shown in Fig. 13. The control scheme for a DFIG system is given in Fig. 14 and it is referred to from [11] to [16].

The operating sequence of the system for simulation is described as follows:

Fig. 14. Control block diagram of DFIG.

(a) Rotor-side converter.

(b) Grid-side converter.

\section{TABLE III}

PARAMETERS OF 2 [MW] DFIG FOR SimUlation

\begin{tabular}{|l|l|}
\hline Rated power & $2[\mathrm{MW}]$ \\
\hline Grid voltage & $33[\mathrm{kV}]$ \\
\hline Stator voltage/frequency & $690[\mathrm{~V}] / 60[\mathrm{~Hz}]$ \\
\hline Stator resistance & $0.00488[\mathrm{p} . \mathrm{u}]$ \\
\hline Rotor resistance & $0.00549[\mathrm{p} . \mathrm{u}]$ \\
\hline Stator leakage inductance & $0.0924[\mathrm{p} . \mathrm{u}]$ \\
\hline Rotor leakage inductance & $0.0995[\mathrm{p} . \mathrm{u}]$ \\
\hline
\end{tabular}

During the time period from 0 to $0.2 \mathrm{sec}$, both of the switches SW1 and SW2 are turned on. The control system has not been activated yet. Therefore, the function model of the back-to-back PWM converters has not been operated. Then the control system is activated between 0.2 and $0.5 \mathrm{sec}$. Thus the function model of the converters works. After 0.5 seconds, the synchronization process is performed before connecting the stator to the grid when the switch SW3 is closed.

\section{Simulation Results}

The proposed function models have been implemented using the DFIG wind power system using back-to-back PWM converters shown in Fig. 13.

PSCAD/EMTDC software (Ver. 4.1.2) is installed on a personal computer with a $2.4 \mathrm{GHz} \mathrm{CPU}$ and $2 \mathrm{~GB}$ of RAM [17]. The simulation parameters (step size: $1 \mu$ s and run time: $1.5 \mathrm{sec}$ ) are set up for the two examples mentioned before. 


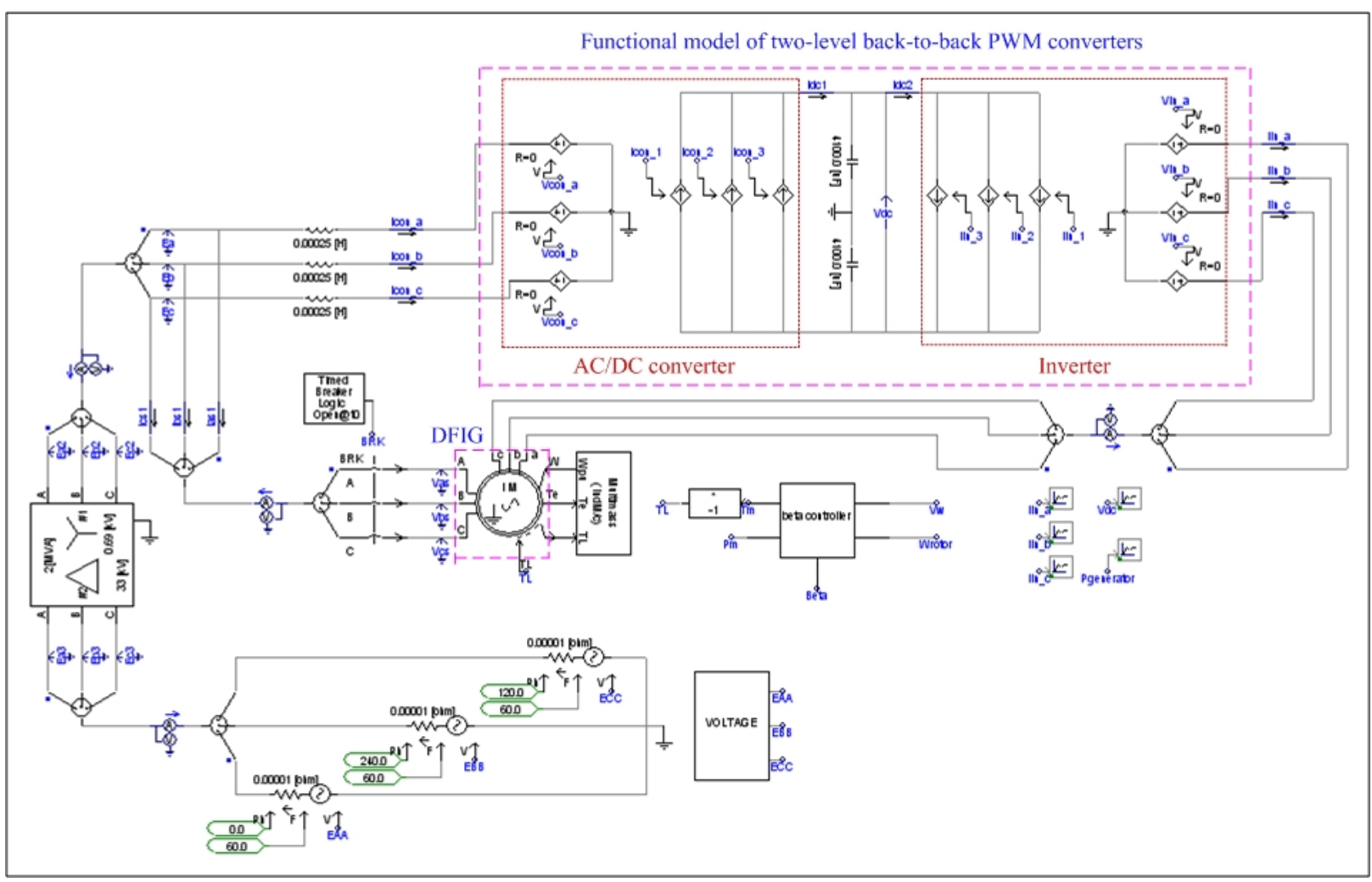

Fig. 15. Schematic diagram of DFIG system using function model of two-level back-to-back PWM converters in PSCAD simulation.

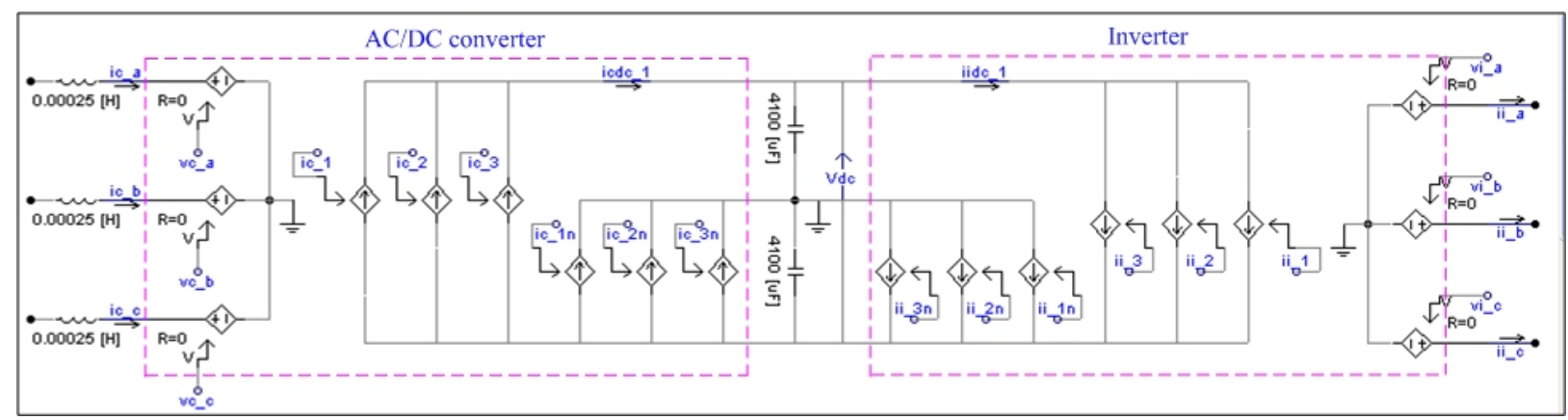

Fig. 16. Function model of three-level back-to-back PWM converters in PSCAD simulation for DFIG system.

The power rating of the DFIG is $2[\mathrm{MW}]$, the grid voltage is $33[\mathrm{kV}]$, the grid frequency is $60[\mathrm{~Hz}]$, and the DC-link voltage references for 2-level and 3-level back-to-back PWM converters are $1[\mathrm{kV}]$ and $1.2[\mathrm{kV}]$, respectively.

The switching frequency for both converters is $2.5[\mathrm{kHz}]$. The DFIG system is connected to the grid through a transformer with turn ratio of 33/0.69. Also, the other parameters of the DFIG are given in Table III.

Using PSCAD, the simplified equivalent circuit being composed of three AC controlled-voltage sources and three DC controlled-current sources can be substituted for each converter in two-level back-to-back PWM converters as shown in Fig. 15. Unlike the function model of two-level back-toback PWM converters, the three AC controlled-voltage sources and the six DC controlled-current sources are considered as a simplified equivalent circuit for each of the three-level PWM converters in Fig. 16.

A simulation for a DFIG system has been performed for both the switching device model and the function model of back-to-back PWM converters. In the case of two-level PWM converters, the DC-link voltages, rotor currents and grid real powers are shown in Fig. 17, 18, and 19, respectively. The simulation results are almost the same for the device model and the functional model of the converters.

Fig. 20-22 show the simulation performances for the threelevel back-to-back PWM converters, where both models give almost the same results.

As expected, the percentages of simulation time reduction for both two-level and three-level back-to-back PWM converters for a DFIG wind turbine system, shown in Table IV, are about $59.54 \%$ and $84.01 \%$, respectively.

\section{CONCLUSIONS}

Functional models for two-level and three-level back-toback PWM converters using switching functions have been developed for simplified simulation. The function models 
TABLE IV

COMPARISON OF SIMULATION EXECUTION TIME

\begin{tabular}{|c|c|c|c|}
\hline Level & $\begin{array}{c}\text { Device model } \\
\text { (second) }\end{array}$ & $\begin{array}{c}\text { Function model } \\
\text { (second) }\end{array}$ & $\begin{array}{c}\text { Simulation time } \\
\text { reduction }(\%)\end{array}$ \\
\hline 2-level & 351 & 142 & 59.54 \\
\hline 3-level & 963 & 154 & 84.01 \\
\hline
\end{tabular}
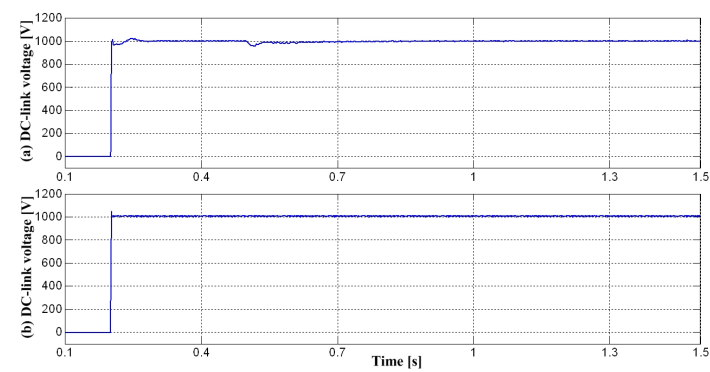

Fig. 17. DC-link voltage waveforms for two-level back-to-back PWM converters in simulation in DFIG systems using

(a) Converter topology.

(b) Function model.
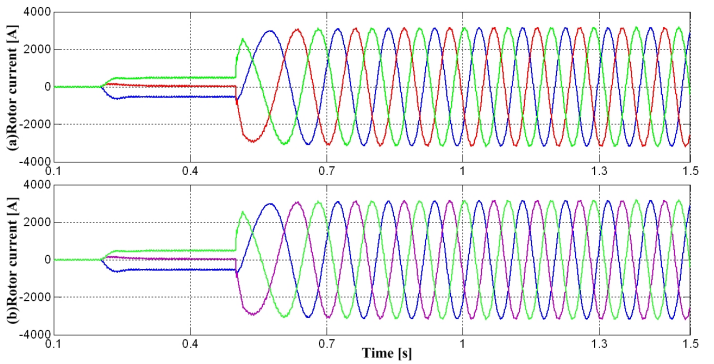

Fig. 18. Rotor currents of DFIG for two-level back-to-back PWM converters from simulation using

(a) Converter topology.

(b) Function model.
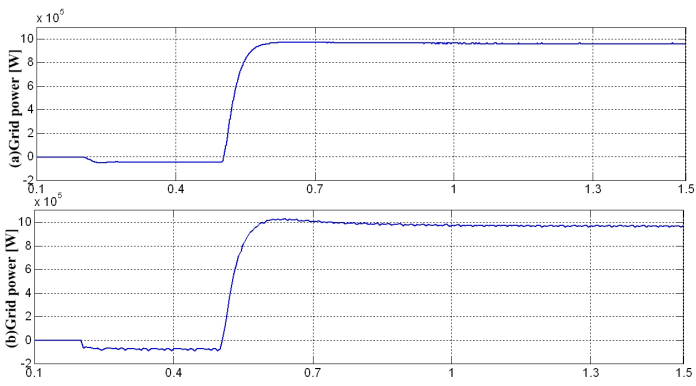

Fig. 19. Real power of grid for two-level back-to-back PWM converters from simulation in DFIG systems using

(a) Converter topology.

(b) Function model.
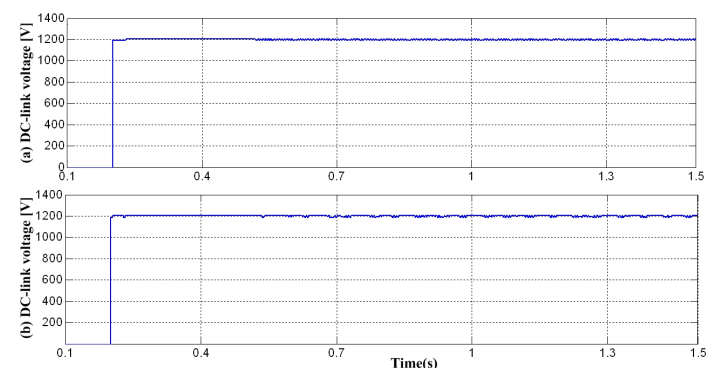

Fig. 20. DC-link voltage waveforms for three-level back-to-back PWM converters in simulation in DFIG systems using

(a) Converter topology.

(b) Function model.

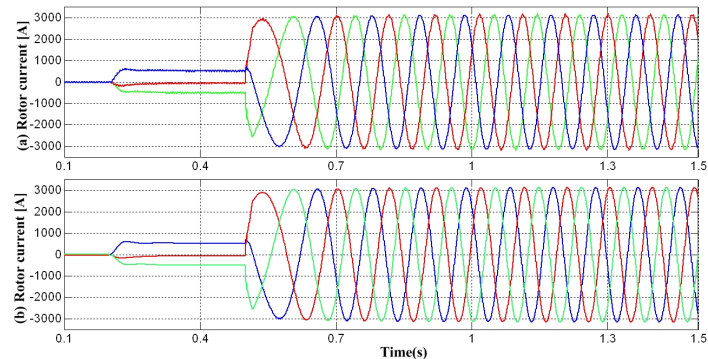

Fig. 21. Rotor currents of DFIG for three-level back-to-back PWM converters from simulation using

(a) Converter topology.

(b) Function model.
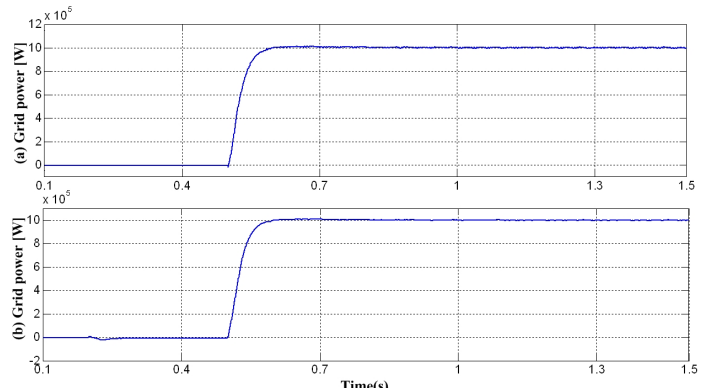

Fig. 22. Real power of grid for three-level back-to-back PWM converters from simulation in DFIG systems using

(a) Converter topology.

(b) Function model.

have been implemented using PSCAD/EMTDC software for application examples of DFIG wind turbine systems. With the proposed function models, the simulation running time for both cases has been significantly reduced without a loss in simulation accuracy. The function model of a converter with higher levels of switching states gives a much greater reduction in simulation execution time. The developed function models can be effectively utilized for design and analysis in the fields of power electronics and power system applications.

\section{ACKNOWLEDGMENT}

This research was supported by Yeungnam University research grants in 2009.

\section{REFERENCES}

[1] L. Salazar and G. Joos, "PSPICE simulation of three-phase inverters by means of switching functions," IEEE Trans. Power Electron., Vol. 9, No. 1, pp. 35-42, Feb. 1994.

[2] E. P. Wiechmann, P. D. Ziogas, and V. R. Stefanovic, "Generalized functional model for three phase PWM inverter/rectifier converters," IEEE Trans. Ind. Appl., Vol. IA-23, No. 2, pp. 236-246, Mar. 1987.

[3] P. D. Ziogas, E. P.Wiechmann, and V. R. Stefanovic, "A computer-aided analysis and design approach for static voltage source inverter," IEEE Trans. Ind. Appl., Vol. IA-21, No. 5, pp. 1234-1241, Sep./Oct. 1985.

[4] B. K. Lee and M. Ehsani, "A simplified functional simulation model for three-phase inverter using switching function concept," IEEE Trans. Ind. Electron., Vol. 48, No. 2, pp. 309-321, Apr. 2001.

[5] P. K. Chaturvedi, S. Jain, P. Agrawal, R. K. Nema and K. K. Sao, "Switching losses and harmonic investigation in multilevel inverters," IETE Journal of research, Vol. 54, Issue 4, pp. 297-307, Jul./Aug. 2008.

[6] J. Rodríguez, J. S. Lai, and Fang Zheng Peng, "Multilevel inverters: A survey of topologies, controls, and applications," IEEE Trans. Ind. Electron., Vol. 49, No. 4, pp. 724-738, Aug. 2002.

[7] B. Wu, High-Power Converters and AC Drives, IEEE Press, Canada, 2006. 
[8] H. T. Mouton, "Natural balancing of three-level neutral-point-clamped PWM inverters," IEEE Trans. Ind. Electron., Vol. 49, No. 5, pp. 10171025, Oct. 2002.

[9] D. B. Crittenden, "Design of a neutral point clamped power inverter," M.S. thesis, Texas Tech University, U.S.A, Dec. 1996.

[10] P. K. Chaturvedi, S. K. Jain, P. Agrawal, and P. K. Modi, "Investigations on different multilevel inverter control techniques by simulation," in the proc. Of PEDES-2006, pp. 1-6, Dec. 2006.

[11] R. Pena, J. C. Clare, and G. M. Asher, "Doubly-fed induction generator using back-to-back PWM converter and its application to variable-speed wind-energy generation," IEE Proc. Electric Power Appl., Vol. 143, No. 3, pp. 231-241, May 1996.

[12] V. Akhmatov, "Analysis of dynamic behavior of electric power systems with large amount of wind power," Ph.D. dissertation, Technical University of Denmark, Kgs. Lyngby, Denmark, Apr. 2003.

[13] A. Yazdani, and R. Iravani, "A generalized state-space averaged model of the three-level NPC converter for systematic dc-voltage-balancer and current-controller design," IEEE Trans. Power Del. Vol. 20, No. 2, pp. 1105-1114, Apr. 2005.

[14] M. Abbes,J. Belhadj and A. B. A. Bennani, "Design and control of a direct drive wind turbine equipped with multilevel converters," Renewable Energy, Nov. 2009.

[15] S. T. Jou, S. B. Lee, Y. B. Park, and K. B. Lee, "Direct power control of a DFIG in wind turbines to improve dynamic responses," Journal of Power Electronics, Vol. 9. No. 5 pp. 781-790, Sep. 2009.

[16] G. Byeon, I. K. Park , and G. Jang, "Modeling and control of a doublyfed induction generator (DFIG) wind power generation system for realtime simulations," Journal of Electrical Engineering and Technology, Vol. 5, No. 1, pp. 61-69, 2010.
[17] Manitoba, HVDC Research Center -PSCADhttps://pscad.com/index.cfm.

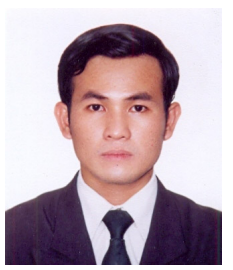

Tan Luong Van was born in Vietnam, in 1979. He received his B.S. and M.S. in Electrical Engineering from the University of Technology, Ho Chi Minh city, Vietnam, in 2003 and 2005, respectively. He is currently working torward his Ph.D. at Yeungnam University, Korea. He was a Lecturer at Ho Chi Minh City Electric Power College, Viet Nam in 2003. His research interests include power converters, wind power generation, power quality, and power systems.

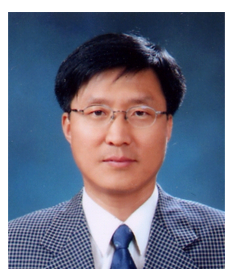

Dong-Choon Lee received his B.S., M.S., and Ph.D. in Electrical Engineering from Seoul National University, Seoul, Korea, in 1985, 1987, and 1993, respectively. He was a Research Engineer with Daewoo Heavy Industry from 1987 to 1988 . Since 1994, he has been a Faculty Member in the Dept. of Electrical Engineering, Yeungnam University, Gyeongbuk, Korea. As a Visiting Scholar, he joined the Power Quality Laboratory, Texas A\&M University, College Station in 1998, the Electrical Drive Center, University of Nottingham, U.K. in 2001, and the Wisconsin Electric Machines and Power Electronic Consortium, University of Wisconsin, Madison in 2004. His research interests include ac machine drives, control of power converters, wind power generation, and power quality. 